\title{
DEL SEÑORÍO MEDIEVAL A LA JURISDICCIÓN SEÑORIAL EN GALICIA: TRANSFORMACIONES Y CAMBIOS ENTRE LOS SIGLOS XIV Y XVI ${ }^{1}$
}

\author{
Rodrigo Pousa Diéguez ${ }^{2}$ \\ Universidad de Vigo
}

Recibido: 2 de mayo de 2017

Aceptado: 11 de junio de 2017

\begin{abstract}
Resumen
El territorio gallego es desde sus orígenes medievales un espacio fuertemente señorializado. No obstante, y pese al carácter feudal de estas estructuras, los señoríos gallegos no constituyeron una realidad feudal en sí misma, tampoco homogénea, ni menos estática, sino que experimentaron numerosos cambios durante la Baja Edad Media hasta configurarse como los señoríos jurisdiccionales que llegan a la Edad Moderna. El presente artículo intenta ofrecer una visión global caracterizadora de estos señoríos, sus orígenes, evolución y transformación en las jurisdicciones de la Galicia Moderna. Para ello se recurre al análisis comparativo de un buen número de señoríos laicos y eclesiásticos y la documentación generada por ellos a través de los siglos.
\end{abstract}

\section{Palabras clave}

Corona de Castilla; jurisdicción; señorío; jueces; notarios.

\begin{abstract}
Galician Kingdom was since its origins in the Middle Ages a feudal territory consisting of multiple manors. However, despite their feudal nature, Galician manors did not correspond to a uniform, homogeneous or static reality, but undergone important changes along the Late Middle Ages, until turning into modern jurisdictional manors. This article aims to offer an overall picture of the main characteristics of these manors, their origins and evolution. To this end, we draw on the comparative analysis of several examples of secular and ecclesiastical manors and the documentation generated by these manors.
\end{abstract}

\section{Keywords}

Castile Crown; jurisdiction; manor; judges; notaries.

\footnotetext{
1 Abreviaturas utilizadas: AGS $=$ Archivo General de Simancas, ARCHV = Archivo Real Chancillería de Valladolid, $\mathrm{AHPOU}=$ Archivo Histórico Provincial de Ourense, $\mathrm{ARG}=$ Archivo Reino de Galicia, $\mathrm{CE}=$ Catastro de Ensenada, $\mathrm{RG}=$ Respuestas Generales.

2 Correo electrónico: rodrigopousa@gmail.com. ORCID: http://orcid.org/0000-0001-9323-8728.
} 


\section{Resumo}

O territorio galego é dende as súas orixes medievais un espazo fortemente señorializado. Pese a iso, e o carácter feudal das súas estruturas, os señoríos galegos non conformaron unha realidad feudal en sí mesma, tampouco homoxénea nin inmutable, senón que sufriron diversos cambios durante a Baixa Idade Media ata configurarse como os señoríos xurisdicionais que chegan a Idade Moderna. $\mathrm{O}$ presente artigo intenta ofrecer unha visión global caracterizadora destes señoríos, a súa orixe, evolución e transformación nas xurisdicións da Galiza Moderna. Para obter esta panorámica recúrrese a análise comparativa dun bo número de señoríos laicos e eclesiásticos, i á documentación xerada polos mesmos ó longo dos séculos.

\section{Palabras chave}

Corona de Castela; xurisdición; señorío; xuices; notarios.

Las diferencias existentes entre los señoríos medievales gallegos y las jurisdicciones modernas son evidentes. Menos evidentes son: su evolución hasta alcanzar la forma con que llegan al siglo XVII, y cuáles fueron las causas y el proceso de transformación -entre el siglo XIV y la primera mitad del XVI-. La intención del presente trabajo es analizar los cambios experimentados por estos señoríos, y su entramado jurídico-administrativo, desde sus orígenes hasta su conversión en señoríos jurisdiccionales modernos.

Los señoríos bajomedievales gallegos estaban compuestos por las tierras pertenecientes a un señor o institución, sobre las que su dueño poseía diferentes prerrogativas, adquiridas por privilegio o prescripción inmemorial. Estaban gobernadas por oficiales diversos -alcaldes, merinos, etc.- que pertenecían a las redes clientelares de la casa o institución $^{3}$, unidos a ella por un vínculo feudal o vasallático ${ }^{4}$. A diferencia de lo que sucedía en Francia, en la España medieval no llegó a consolidarse un Estado y una Sociedad feudal en sí misma, por lo que ha preferido hablarse de señorío ${ }^{5}$ ¿Eran señoríos y no feudos lo que encontramos en la Galicia Medieval? ¿Qué tipo de prerrogativas poseían los señores sobre su término?¿Eran homogéneas estas prerrogativas?¿Permanecieron inalteradas como corresponde a un derecho otorgado por concesión regio? ¿Preservaron los señoríos su unidad territorial en el devenir secular? Otra cuestión que se podría plantear aquí es la de si se debe hablar en Galicia, como en el resto del reino Asturleonés de señorío o deberíamos llamarle dominio ${ }^{6}$.

Todas estas cuestiones han permanecido a un lado para la historiografía medieval gallega, cuyos trabajos se han centrado en sacar a la luz los documentos conservados de las principales entidades señoriales de Galicia: Monasterios y Nobleza. El territorio y su articulación administrativa han permanecido en un segundo plano en las numerosas

\footnotetext{
GARCía Oro, La nobleza gallega en la Baja Edad Media: las casas nobles y sus relaciones estamentales. 4 García Oro, La nobleza gallega en la Baja Edad Media: las casas nobles y sus relaciones estamentales, pp. 253-285.

5 Véase García Valdeavellano Arcimís, "La cuestión del feudalismo hispánico", pp. 7-62. Y también la obra coordinada por Serrano Martín y Sarasa Sánchez, Señorío y feudalismo en la Península Ibérica.

6 Grassoti, "Dominus y dominum en la terminología jurídica de Asturias, León y Castilla (siglos IX-XIII)", pp. 654-682.
} 
monografías dedicadas a los señoríos monásticos y a las grandes casas nobles del Bajo Medievo. Todos estos trabajos nos proporcionan a día de hoy un número de casos suficiente para abordar la cuestión que nos ocupa. El ánimo del presente trabajo no es sino ofrecer una primera aproximación, panorámica, pero prismática, sobre la articulación del señorío medieval gallego, que culmina con la cristalización de los señoríos jurisdiccionales que en la Modernidad abarcan el 90\% del territorio.

En la Edad Moderna, el señorío aparece compuesto por dos tipos de tierras -claramente diferenciados, en función del dominio que se ejerce sobre ellas-: las de dominio directo y las de dominio jurisdiccional ${ }^{7}$. Son las de segundo tipo las que, por su naturaleza, convierten a su dueño en señor, y a los pobladores en sus vasallos. Además las jurisdicciones modernas gallegas presentan una estructura muy semejante; ya que todas las que se configuraron como tales confirieron a su señor amplias prerrogativas judiciales, -y frecuentemente- administrativas y gubernativas. Los señores jurisdiccionales gallegos poseían -en su mayoría- jurisdicción civil y criminal sobre sus vasallos. Esto es, capacidad para juzgar y conocer judicialmente todo tipo de causas, tanto civiles como criminales. A esta le acompañaba el mero y misto imperio, que les permitía punir y castigar tanto los delitos leves como los graves ${ }^{8}$. Esta homogeneidad contrasta profundamente con la disparidad que se percibe en los señoríos medievales, propia de un espacio de poder de tipo tradicional ${ }^{9}$, en que los derechos serían distintos según el modo y momento de apropiación.

La generalización entre los señores gallegos del derecho a impartir justicia reviste especial importancia. La justicia era la principal alhaja de la Corona-como se desprende de los primeros corpus legislativos castellanos $-^{10}$. La posesión de la jurisdicción ordinaria sobre un territorio privaba al monarca y sus oficiales de su ejercicio, además de reforzar el señorío de su propietario y el vínculo con los vasallos; como garante del orden, el derecho y la justicia. El resto de actividades concejiles, administrativas, gubernativas e incluso fiscales pasaban, en su desempeño, a desarrollarse bajo la vigilancia y respaldo de su vara. La cuestión es cómo habían adquirido este derecho ¿Lo habían hecho por privilegio o por posesión inmemorial? ¿En qué cronología?

Para ello resultó clave la figura del juez ordinario, que en nombre del señor impartía justicia -que raramente fue ejercida personalmente por los señores ${ }^{11}-\mathrm{y}$ asumía el resto de labores administrativas, como las de fijar precios, vigilar el uso de pesos y medidas

\footnotetext{
Gullarte Zapatero, El régimen señorial en el siglo XVI, p. 85.

López Díaz, "La administración de la justicia señorial en el Antiguo Régimen”, pp. 557-559.

Hespanha, "El espacio político", pp. 98-100.

10 "Porque la justicia es la más alta virtut, e la mas complidera para el governamiento de los pueblos, porque por ella se mantienen todas las cosas del Estado que deben, e la qual señaladamente son tenudos los Reys de guardar e mantener" (Ordenamiento de Alcalá lib. I).

11 Entre otras cosas porque su ejercicio exigía la obligación de la residencia. Obligación documentada ya en algunas cartas pueblas como la de Muros de 1285 y contenida en la legislación castellana. ARG, Real Audiencia, leg. 22.545, núm. 19, s.f.
} 
y conceder títulos a los artesanos en las jurisdicciones rurales ${ }^{12}$; además de otras que emanan de su condición de juez, como podían ser las de conceder curadores a los menores, realizar inventarios post mortem, etc. Por encima de estos jueces ordinarios se encontraban los alcaldes mayores, que los grandes monasterios y señores de vasallos -documentados en las grandes casas de Altamira, Lemos, Monterrey, Ribadavia- crearon en el siglo $\mathrm{XV}^{13}$. A los agentes de la administración señorial moderna ya descritos se añadirían otros más variables, en presencia y funciones, de un señorío a otro; tanto en la administración señorial central, como en las jurisdicciones (alguaciles, carceleros, etc.), que los señores y sus delegados supieron utilizar para lucrarse económicamente y nutrir sus redes clientelares.

Los señoríos gallegos experimentan cambios significativos durante la Baja Edad Media, tanto en lo que respecta a su naturaleza como a su administración. Estos cambios afectan de distinta manera a cada uno de ellos y se producen en una cronología bastante amplia, con frecuencia de difícil precisión. Para los cambios que aquí se intentan analizar, se ha establecido como eje cronológico el período comprendido entre el siglo XIV y el primer cuarto del siglo XVII, cuando las jurisdicciones adquieren la forma definitiva con la que llegan al XVIII ${ }^{14}$.

Entre los cambios que se observan en muchos señoríos gallegos bajomedievales y los señoríos del siglo XVII, deben indicarse primeramente los que inciden sobre el territorio, como base sobre la que el señor establece su dominio. Estos cambios en el territorio guardan a su vez relación directa con otros cambios de más profundo calado, que tienen que ver con la propia definición de señorío y las prerrogativas que implica ser señor de ese territorio. Estas transformaciones dan lugar a toda una serie de pleitos -concentrados principalmente entre finales del siglo XV y el siglo XVI- por la posesión de la jurisdicción de estas tierras ${ }^{15}$; entre todos aquellos que por cuestiones hereditarias, posesión del dominio directo y prestaciones vasalláticas diversas, o bien por posesión inmemorial reclamaban el señorío jurisdiccional. Las contiendas se producirán ante los tribunales de la Corona, configurados entre el siglo XV y el XVI, como son la Real Audiencia de Galicia y la Chancillería de Valladolid. Sus sentencias serán las que confirmen o recreen los nuevos señoríos, con un aspecto diferente al que habían poseído hasta entonces.

\section{Los privilegios: ¿orígenes del señorío jurisdiccional?}

Un señorío podía adquirirse, según el derecho castellano, por dos vías fundamentales: privilegio expreso o posesión inmemorial. El primer problema con que nos encontramos para averiguar si los señoríos jurisdiccionales fueron adquiridos mediante donación

\footnotetext{
12 Es el caso de Orcellón perteneciente al conde de Monterrey, la jurisdicción de Corcubión perteneciente al conde de Altamira, o las de Muros y Noia pertenecientes al arzobispo de Santiago.

13 SAAVEdra Fernández, "La administración señorial en la Galicia Moderna”, pp. 185-212.

14 Eiras Roel, "El señorío gallego en cifras: nómina y ranking de señores jurisdiccionales", pp. 7-46.

15 Oliveira Serrano, "Los señores del Estado de Monterrey", pp. 285-315.
} 
regia es la carencia de buena parte de estos privilegios. Esto se debe entre otras cosas a la antigüedad de buena parte de los dominios señoriales gallegos - entre ellos los monásticos, cuya documentación es la que ha llegado a nosotros de forma más completa-. Dentro del señorío monástico, los monasterios benedictinos recibieron de las familias a las que deben su fundación, junto otras recibidas de la Corona, buena parte de las tierras sobre las que después ejercieron su señorío. Muchas de ellas no se han conservado, y algunas de las donaciones que recibieron de los monarcas son tan inexactas como variables entre ellas - pese a que al llegar en XVI la mayoría ostentan sobre sus cotos y señoríos la jurisdicción plena-.

Los privilegios más claros a este respecto probablemente sean los del Emperador Alfonso VII. Entre ellos, el privilegio de coto concedido al monasterio de Dozón es de los más explícitos en sus concesiones, sin embargo, está lejos de constatarse en él la transmisión del derecho a impartir justicia ${ }^{16}$. En 1121 se concede otro privilegio de coto concedido a Oduario Ordóñez de las tierras del monasterio de San Miguel de Bóveda y las iglesias de San Paio de Bóveda y Santa Baia de Beiro, con cláusulas semejantes: ut ab hodierno die sin tille vestre hereditates honorate et cautate tam a nobis quam a notris vicariis et procuratoribus, sive etiam ab ómnibus viventibus, et nunquam ingrediatur in illud cautum maiordomus meus pro aliqua calumnia requirenda, nec vicarius, nec sagionus, nisi unde proprius fuerit et per vestram voluntatem intraverit ${ }^{17}$.

En 1129 el mismo monarca concede otro privilegio de coto al monasterio lucense de Ferreira de Pallares con cláusulas similares ${ }^{18}$. Y en 1152 acota al monasterio de Monfero los dominios de su entorno ponimus praefatae aecclesiae cautum atque defensionem, quod nullus homo audeat irrumpere a termino quod dicitur Mamolas de Frexeno, deinde... ${ }^{19}$. También Alfonso VII concede a San Pedro de Rocas un coto. Estos son quizá de los más claros, yaque al limitar la intervención regia en él, y que nadie pueda prendar en su territorio, manifiesta la independencia jurídica de él ${ }^{20}$.

Moxó identificó entre las donaciones de Alfonso VII -recopiladas por Peter Rasow- la cesión de prerrogativas realengas, y entre ellas la de justicia en cláusulas como: com tuto suo directo, com tuto suo foro et suo directo o sicut ad regale ius pertinet ${ }^{21}$. Claro

\footnotetext{
16 Fernández Viana Vieites, Colección diplomática do mosteiro de San Pedro de Vilanova de Dozón, p. 54.

17 Fernández Fernández, O mosteiro feminino de San Miguel de Bóveda, p. 120.

18 "sic dono atque concedo hec omnia que infra hos términos continentur vobis iam dicte ut habeat et possideat ad sustentanionem monachorum in ipso monasterio degentium in perpetuum. Si vero aliquis hoc meum factum inrumpendum tamptaverit, pariat ad partem monasterii $\mathrm{cm}$ libras auri purissimi et cuod inuaserit duplet et hac carta Semper sit firma". Rey CAî̃̃a, Colección diplomática de Ferreira de Pallares, p. 297.

19 López Sangil, Historia del monasterio de Santa María de Monfero, p. 111.

20 "et nullus maiorimus vel sagio regis vel alicuius hominis sit ausus pignorare vel aliquod malum facere in omni termino istius cauti". En el mismo año de 1153 concede también el privilegio de coto sobre la "villa" de Velle con unas cláusulas exactamente iguales: "et nullus maiorinus vel sagio regis vel alicuius hominis sit aussus pignorare vel aliquod malum facere in omni termino istius cauti”. DuRo PEÑA, El monasterio de San Pedro de Rocas y su colección documental, pp. 138-139.

21 Moxó Ortiz de Villajos, Feudalismo, señorío y nobleza en la Castilla Medieval, p. 145.
} 
que al afirmarlo incluye la justicia como uno de los derechos reales susceptibles de enajenación, por incluirse en alguna donación como la de la villa de Cerama en 1127 et saco inde tibi sagionem, rausum, homicidium, fossadariam et abeas ista et cetera que ad regale ius pertinet. La cuestión es, si esto fue lo que se pretendía en todas ellas, aun cuando no se especificaba, siendo más que sospechoso que en esta última se especifique con tanto detalle, mientras las demás podrían referirse tan solo a la transmisión del solariego.

Más claro parece el traspaso de otras prerrogativas, como las de recaudar tributos o reclutar a los hombres que sirvieron en las milicias señoriales, cuando se incluye en las donaciones el traspaso de los hombres. E igualmente, el que las prerrogativas traspasadas no pudieron ser las mismas por todos los monarcas, ni a todos los señores. Moxó reconoce varios casos en donde los privilegios a los que se remitían los señores no eran justificadores de las prerrogativas jurisdiccionales que ejercieron -como el del monasterio cisterciense de Monsalud-. Otro ejemplo fue el choque de los señores que reclamaban la jurisdicción con la justicia de los locales, que se dio en Tortosa ${ }^{22}$. Y que recuerdan a los habidos entre el Arzobispo y el concejo de Santiago ${ }^{23}$.

Fernando II continúa la tendencia concesionaria de espacios acotados a los monasterios gallegos de su padre, pero sus cláusulas plantean una problemática muy similar. Un ejemplo de ello es la donación al monasterio de San Esteban de San Cristóbal de Armariz cum toto suo cauto, et ómnibus directuris et pertinenciis suis ${ }^{24}$, o el acotamiento en 1177 al monasterio de Monfero de San Pedro de Buriz y Santa María de Labrada ${ }^{25}$. Todo ello entra en contraste con lo recogido en el fuero viejo de Castilla, redactado durante el siglo XIII -en torno a 1248- como recopilación del derecho medieval castellano, que declara el derecho a impartir justicia como una prerrogativa exclusiva del monarca, cuyo texto se atribuye a Alfonso VII en las Cortes Nájera del siglo XII ${ }^{26}$ Estas cuatro cosas son naturales del señorío del rey, que non las debe dar a ningún ome, nin las partir de sí, ca pertenscen a él por razón del señorío natural: Justicia, moneda, fonsadera e suos yantares. (Fuero Viejo, lib. I, tit. I, 1. 1).

En las Partidas Alfonso X definió el mero imperio como la potestad de juzgar pleito sobre que puede ser dada sentencia de muerte o de pedimento de miembro, o de echamiento de tierra, o desterramiento de ombre en servidumbre o darle por libre. En ellas se limitaba la posibilidad de adquirirlo por posesión inmemorial, por ser una alhaja propia de Emperadores y los Reyes e los otros grandes príncipes que eran a judgar las tierras e las gentes dellas. Ca otro ombre no lo puede ganar ni aver por linaje nin por uso de luengo tiempo si señaladamente no le fuere otorgado por privilegio.

\footnotetext{
2 Moxó Ortiz de Villajos, Feudalismo, señorio y nobleza en la Castilla Medieval, p. 154.

23 López Díaz, Señorío y municipalidad: convergencia y conflicto de poderes en la ciudad de Santiago, p. 22.

24 Duro Peña, El monasterio de San Esteban de Ribas de Sil, p. 251.

5 Martínez Salazar, Crónica Troyana: códice gallego del siglo XIV, pp. 453-454.

26 Bermejo Cabrero, "En torno a las Cortes de Nájera", pp. 245-249.
} 
Menos trabas se ponían a la posesión del misto imperio definido como la potestad para dar guardadores a huérfanos o locos o desmemoriados o apoderar a algunos querellosos en tenencia de bienes que fueran de otro, mostrando razón derecha como les pertenece la herencia dellos, o de otra cosa qualquier por alguna razón guisada, o librar pleito que sea de trezientos maravedies de oro en arriva ${ }^{27}$. Pese a ello, la necesidad en las Cortes de Zamora de 1274 de fijar los ocho casos de corte, reservados a la justicia del monarca parece indicar que ya se estaban produciendo apropiaciones en materia de administración de justicia por los señores ${ }^{28}$.

En la documentación regia la locución merum imperium solo comienza a aparecer a partir de 1304 y en casos contados -como en las donaciones hechas al nieto Alfonso $\mathrm{X}$ por el Tratado de Torrellas-. La incompatibilidad con la realidad jurídica del reino hizo que Fernando "El emplazado" en 1306 pidiese que no se usase de aquellas cartas. Esto -junto la donación explícita a Juan Alfonso Benavides en 1300 con señorío de justicia ${ }^{29}$ - parece dejar claro que en los privilegios gallegos de la época, en que no se contiene explícitamente, no se pretendía el traspaso de tales prerrogativas. De un modo semejante, en tiempo de Alfonso XI sí se produjeron algunos traspasos de justicia, como el hecho a Ruy Páez Biedma de la tierra de Portela, pero la locución mero y misto imperio se utilizó solo en las donaciones a sus bastardos y a algunos funcionarios de la Corte ${ }^{30}$. Por la misma época en la Corona Aragonesa, las Cortes de Barcelona de 1283 consideraban que la acumulación del mero y misto imperio componían una omnimmodam iuristionem altam et baxam que correspondía en exclusiva a los príncipes, salvo cesión explícita ${ }^{31}$.

Los privilegios y confirmaciones de Alfonso IX de varios regalengui concedidos al monasterio de San Xusto de Toxos Outos, vuelven a resultar muy opacos y genéricos en cuanto a lo que se transfiere:

- dono atque concedo istum cautum huic monasterio et sancte congregationi eiusdem ut nullus sayo vel vicarius regis seu alicuius potestatis non sit ausus ab hodierno die... ${ }^{32}$

- ut hab ac die et deinceps prefactum realegnum habeatis cum pratis, pascuis... ${ }^{33}$

- cum onibus suis appendiciis et cum homnibus intus et foras morantibus... ${ }^{34}$

\footnotetext{
27 Partida III, IV, 18 cfr. Bermúdez Aznar, El corregidor en Castilla durante la Baja Edad Media (13481474), p. 175.

28 Ayala Martínez, Las órdenes militares hispánicas en la Edad Media, p. 655.

29 GrasotTi, Novedad y tradición en las donaciones con mero y mixto imperio en León y Castilla. Homenaje al profesor Juan Torres Fontes, pp. 723-724.

30 Grasotti, Novedad y tradición en las donaciones con mero y mixto imperio en León y Castilla. Homenaje al profesor Juan Torres Fontes, p. 725.

31 García Valdeavellano Arcimís, Señores y burgueses en la Edad Media Hispana, p. 148.

32 Pérez Rodríguez, Os documentos do Tombo de Toxosoutos, p. 85.

33 Pérez Rodríguez, Os documentos do Tombo de Toxosoutos, p. 86.

34 Pérez Rodríguez, Os documentos do Tombo de Toxosoutos, p. 88.
} 
- cum omnibus hereditatibus et adiunctionibus suis... ${ }^{35}$

- cum omnibus directuris et pertinenciis suis... ${ }^{36}$

En 1214 Alfonso IX confirma al monasterio de San Esteban de Ribas de Sil la posesión de su coto, restringiendo la intervención incluso de los oficiales regios, como sucedía en los privilegios de coto de Alfonso VII y Fernando II ${ }^{37}$. No obstante, en 1215 define las prerrogativas y exenciones del coto del monasterio, entre las que se encuentra la autorización al abad para administrar justicia: et si Abbas vocaverit illos, ricome vel meyrinus faciant ibi suam iustitiam ${ }^{38}$. Si bien queda claro que este monasterio gallego contó con capacidades jurisdiccionales desde el siglo XIII, la necesidad de conceder un título como el anterior y uno nuevo en 1220, concediendo al monasterio nombrar juez y notario en el $\operatorname{coto}^{39}$, vuelve a replantear la cuestión de si las cláusulas más genéricas presentes en las donaciones a Toxos Outos conllevaban implícito o no el derecho de sus señores a administrar justicia sobre sus colonos. Y lo mismo en las concesiones hechas al monasterio de Asma por Alfonso IX que incluían varios cotos, uno sobre la feligresía de Santa María de Camporramiro et incauto ipsa villa cum quanto ibi ad regia pertinent vocem, y en el que acota las tierras del monasterio y la «villa» de Nogueira: incauto iam dictum monasterium cum ómnibus rebus et pertinenciis suis, ubicumqui potuerint inveniri, et incauto eidem monaterio villam que dicitur Nogueira ${ }^{40}$.

De nuevo, como sucedía en el caso de San Esteban, es necesario un nuevo privilegio concedido en 1221 que especificaba la prerrogativa del abad a impartir justicia, o más bien que privase a cualquier otro de impartir justicia sobre sus servitiales -lo más interesante de este privilegio radica en que los ejemplos de crímenes juzgables son de naturaleza criminal, lo que suponía la concesión del grado de jurisdicción más elevado ${ }^{41}$. A tenor de lo expuesto, parece que la intención de los monarcas iba dirigida a conceder a estos monasterios autonomía y protección frente a la intervención de aquellos ricoshombres y oficiales a los que prohíbe intervenir en sus tierras. Y solo en el caso Alfonso IX se dona específicamente la capacidad para impartir justicia.

El gran monasterio de Celanova, que en la Edad Moderna contará con más vasallos que ningún otro ${ }^{42}$, disponía de un coto supuestamente concedido por Alfonso VII sobre

\footnotetext{
35 Pérez Rodríguez, Os documentos do Tombo de Toxosoutos, p. 89.

36 Pérez Rodríguez, Os documentos do Tombo de Toxosoutos, p. 91.

37 Duro PeÑa, El monasterio de San Esteban de Ribas de Sil, pp. 256-257.

38 Duro Peña, El monasterio de San Esteban de Ribas de Sil, p. 260.

39 Duro Peña, El monasterio de San Esteban de Ribas de Sil, p. 264-265.

40 Duro Peña, El monasterio de San Esteban de Ribas de Sil, pp. 187-188.
}

41 Excuso homines qui sunt servitiales de Sancto Salvatore de Chantada, de homicidio et de furto e de rouso et de tota voce, et de tota enliza, et de tota voce ita quod de predictis vocibus nulli hominum teneantur responderé nisi abati et monasterio ante dicto; quito inqua et excuso predictos servitiales iam dicto abati et monasterio ubicumque ex haverint in Monterroso, in Camba, in asma, in Lemos, in Decia et in Cusanca, in Salnés et per totam Gallaeciam.

42 SaAVedra Fernández, "Los señoríos de las grandes órdenes monásticas en la Galicia Moderna: una visión Global”, pp. 277-280. 
el que en el siglo XVI posee jurisdicción plena. Pese a ello, en el reinado de Alfonso IX el propio monarca no tenía muy claro que tipo de prerrogativas podía poseer Celanova sobre aquellas tierras. En su privilegio concedido en 1216 se limitaba a garantizar la autonomía y protección de este: ut de caetero nullus ricus homo habeat vel teneat ipsam comendam, nec sagio, nec majordomus, nec aliquis alius intret ibi pro voce regia, nisi forte ad siqua corrigenda, vel ad melius paranda, et vocaverit eu aut demandaverit Abbas qui in ipso monasterio fuerit. A partir de este reinado al menos se reconoce al monasterio de Celanova y su mayordomo la percepción exclusiva de varios derechos señoriales, como la fonsadera o la luctuosa, y el derecho a prendar de los mayordomos de los castillos. En su resolución Alfonso IX limita también la intervención de los mayordomos de realengo cuando dice: ítem invenimus quod maiordomus de regalengo non debet ponere caritellum nec incautare aliquem in Montibus, nisi in Anfeoz pro sua fossadaria; y también al prohibir su intervención en el coto de Riba de Miño: debent etiam isti homines in fosatum Regis ire per mandatum maiordomi Cellanove ${ }^{43}$. Pero no hay constancia de que hasta ese momento Celanova pudiese impartir justicia en sus dominios.

En la misma línea, Fernando III concede un coto a Aciveiro en 1232 sobre la feligresía de San Salvador de Brigos, concedo et cauto vilam et ecclesiam Sancti Salvatoris de Vibros, sin más especificaciones ${ }^{44}$.

Ya a finales de siglo, Sancho IV concede en 1295 todos los derechos pertenecientes al monarca en el coto de San Esteban de Ribas de Sil pero tampoco se hace mención alguna a la prerrogativa de impartir justicia ${ }^{45}$. Y lo mismo hace en el privilegio de coto concedido al monasterio de Chantada: damosles et cotamosles por alma del rey don Fernando, nuestro abuelo, et del rey don Alfonsso, mi padre, et en remission de nuestros pecados, todo lo que nos avemos en la felegresía de Sant Estevan de Chantada, por aquellos logares que Estevan Eanes nuestro iuyz en Monterroso gela entrego ${ }^{46}$.

En 1348 el mismo Alfonso XI convocaría a las Cortes en Alcalá. En el ordenamiento fruto de estas se calca nuevamente el artículo que reserva la justicia como una prerrogativa exclusiva del monarca. Debe entenderse que en este momento el término «justicia» debió limitarse al derecho a legislar, y no al de juzgar y castigar. La novedad frente a Alfonso $\mathrm{X}$ es que en estas cortes el monarca reconoce el derecho a impartir justicia a los señores en sus señoríos, incluso a aquellos que no la tuviesen por privilegio por prescripción inmemorial a aquellos que la hubiesen administrado ${ }^{47}$.

En otros espacios de la Península como en los condados catalanes, ya desde el siglo XIII, se han documentado baronías y castillos que poseían jurisdicción alta y baja y

\footnotetext{
43 Rodríguez Fernández, "Coto de Celanova (Orense) y su fuero", pp. 83-90.

44 Méndez Pérez, Otero Piñeiro Maseda y Romaní Martínez, El monasterio de San Salvador de Chantada. Historia y documentos, p. 194.

45 Fernández Viana Vieites, Colección diplomática do mosteiro de San Pedro de Vilanova de Dozón, pp. 91-92.

46 Fernández Viana Vieites, Colección diplomática do mosteiro de San Pedro de Vilanova de Dozón, p. 220.

47 Colmeiro Penido, Historia de las Cortes de León y de Castilla, pp. 539-540.
} 
mero y misto imperio - como Pallar, Urgell, Cabrera o Ampurias-, frente a otros señoríos como las «cuadras» con unas prerrogativas mucho más limitadas -herederas de las «dominicature» caballerescas ${ }^{48}$.

En el territorio gallego, a parte de las prerrogativas concedidas en los privilegios ya enunciados, no es hasta el siglo XIV cuando se documenta la cesión del derecho a impartir justicia. Uno de los primeros casos es el privilegio concedido en 1364 por Pedro I a Fernando Pérez de Andrade de la feligresía de Narahío con todos sus términos et vasallos, et montes, et pastos, et prados, et justiçias, et sennorio, et pechos, et fueros, e derechos foreros ${ }^{49}$.

No es hasta la segunda mitad del siglo XIV cuando comienzan a aparecer en la documentación gallega las primeras menciones que explicitan el tipo de potestad jurisdiccional de los señores, y a figurar los conceptos de jurisdicción civil y criminal y el mero y misto imperio.

Fernando IV en 1308 intercambia con María Páez, viuda de Fernando Ruiz Biedma, varias tierras y castillos en Murcia, por tierra de Aguiar da Moa y Salas con su castillo y cillero de Laias con todos los pobladores que agora son y serán de aquí adelante y con todos los pechos y fueros y derechos que nos hi habemos haber debemos, y con la justicia y con todo el señorío real ${ }^{50}$. Estas tierras se dividirían después en la jurisdicción de Baltar y la de Salas.

En el privilegio concedido por Enrique II a Juan Rodríguez de Biedma por el que dona Villa de Rey, Soto Bermud, Val de Laza, Castillo de Santibáñez de la Barra, Todea y Peñafiel, es de aquellos en los que queda más claro la donación total de los derechos regios: damosvos dhos lugares con todos sus alfoces e términos, e aldeas, e pertenecías que les pertenecen e pertenecer deben e con todas las rentas, e pechos e dros. De ellos [...] que pertenezcan en qualquiera manera al señorio de los dichos lugares e cada uno den ellos y con las justicia civil, y criminal, e mero e mixto imperio y señorio de los dhos lugares ${ }^{51}$. Este mismo monarca concedió por albalá a Juan Rodríguez de Biedma en 1368 cuatro lugares que nos abemos en tierra de Limia, los cuales son Lovera, Entrimo, Araujo y Abeleda sin especificar más prerrogativas. En 1369 concede los lugares de Xinzo, Miño y Barbantes con la justicia civil e criminal e con todas las rentas, pechos e derechos ${ }^{52}$. La casa de Biedma recibe en 1407 Vilanova dos Infantes, con Castriello (Castromao) e Espinoso con unas cláusulas similares ${ }^{53}$.

También a inicios del XIV, la reina doña Beatriz concede a Pedro Fernández de Andrade, en 1405, la bailía del Burgo de Faro con todas sus aldeas e señorío e con todas sus entradas e salidas e rentas e derechos e pertinendias e con toda su jurisdición

\footnotetext{
48 Cuadrada Majó, "Poder, producción y familia en el mundo rural catalán (siglo XI-XIV)", pp. 236-240.

49 Correa Arias, A casa de Andrade 1160-1540, pp. 592-596.

50 Véase la obra sobre los Estados de Monterrey escrita en 1777 por Pedro González Ulloa en FERNÁNDEZ Oxea, Descripción de los estados de la Casa de Monterrey en Galicia, p. 171.

51 Fernández OXea, Descripción de los estados de la Casa de Monterrey en Galicia, pp. 86-91.

52 Fernández Oxea, Descripción de los estados de la Casa de Monterrey en Galicia, pp.196-197.

53 Fernández Oxea, Descripción de los estados de la Casa de Monterrey en Galicia, pp. 223-224.
} 
cevil e criminal, alta e baja e con todo el justo mero imperio ${ }^{54}$. Lo mismo sucede en la donación hecha en 1440 a don Diego Pérez Sarmiento de la villa de Ortigueira con la justicia e jurediçión çevil e criminal, alta y vaxa e mero misto ymperio ${ }^{55}$. Pero por ejemplo, nada sabemos con certeza de los señoríos de los Ulloa, que por otro lado don Lope Sánchez fue acumulando de distinta forma ${ }^{56}$.

Ayala Martínez ha señalado que las órdenes militares poseían ya a inicios del siglo XIV el mero imperio por privilegio en algunos lugares, aunque los ejemplos aportados se reducen a las Órdenes Montesa y de Santiago, y se limitan a la Corona de Aragón ${ }^{57}$; desconociendo la adquisición de los derechos jurisdiccionales que la Orden de San Juan poseía en sus encomiendas de Glaicia.

Mientras tanto, en otro reino peninsular, en Navarra las donaciones del siglo XIV seguían limitando la jurisdicción concedida a los señores, reservando a la Corona la alta justicia de sangre o la alta señoría y justicia criminal. En un informe del Consejo de Navarra de 1756 se ponía de manifiesto como la alta justicia criminal fue adquirida por los señores durante las enajenaciones de los siglos XVII y XVIII ${ }^{58}$. Esto mostraría un proceso similar, aunque posterior en el tiempo, al que parece observarse en el reino de Galicia, ya que eran muchos los señoríos que al alcanzar la modernidad no podían acreditar mediante privilegio el grado de jurisdicción adquirido, pero que acabaron por arrogárselo todo.

En Francia se había producido una apropiación similar de la potestad jurisdiccional por parte de los señores, un proceso que comienza en época de los primeros Capetos. Se habla de apropiación, partiendo de la tesis defendida por Blosch y Ganshof de que la concesión de un feudo a un vasallo no implicaba la investidura del poder jurisdiccional. Esta apropiación aparece ya documentada en el siglo XI por Boutroche impartiendo justicia y exigiendo tributos en vasallaje ${ }^{59}$.

En los cotos de Troncoso y Couxil, pertenecientes a la Encomienda de A Batundeira, la jurisdicción civil y criminal del XVI tiene un claro origen foral ${ }^{60}$. En estos dos espacios la Encomienda de la Orden de Alcántara poseía todo el solariego, pero no es hasta el siglo XVI cuando comienzan a considerarse como jurisdicciones de pleno derecho. Una muestra de ello es el intento del administrador de la Encomienda de someter a los foreros de estos cotos a un mismo juez don Juan Cruz Alvarado, abad de Bóveda de Amoeiro, documentando después en el siglo XVIII la presencia de jueces independientes, aunque no escribanos numerarios ${ }^{61}$.

\footnotetext{
54 Correa Arias, A casa de Andrade 1160-1540, pp. 617-619.

55 Fernández SuÁrez, La nobleza gallega entre los siglos XIV-XV: los Sarmiento condes de Ribadavia, pp. 346-347.

56 Ferro Couselo, A vida e a fala dos devanceiros, pp. 190-92.

57 Ayala Martínez, Las órdenes militares hispánicas en la Edad Media, pp. 654-655.

58 Usunáriz GaraYoA, "La creación de señoríos en la Navarra del siglo XV y su repercusión durante la Edad Moderna y el proceso de abolición”, p. 1213.

59 Moxó Ortiz de Villajos, Feudalismo, señorio y nobleza en la Castilla Medieval, p. 144.

60 Pallares Méndez, "Los cotos como marco de los derechos feudales en Galicia durante la Edad Media (1100-1500)", pp. 201-225.

${ }^{61}$ AGS, CE, RG, libs. 216 y 220.
} 
Esta misma encomienda trató de reclamar ante la Real Audiencia la jurisdicción sobre el casal de Macendo. En 1561 el Comendador de A Batundeira, don Francisco Alarcón interpone querella ante la Real Audiencia, reivindicando la jurisdicción civil y criminal, con el mero y mixto imperio sobre los vasallos que viven en el casar de Santa María de Macenda. La Real Audiencia da su provisión de emplazamiento a las partes el 3 de octubre de 1561. Los testigos emplazados en el coto de Vide el 22 de diciembre, a tenor de las respuestas de los testigos el tema de la jurisdicción no estaba nada claro, la confusión parece girar en torno a los conceptos jurisdicción y vasallaje, clarificados en el XVIII ${ }^{62}$. Esta confusión en torno al concepto y condición de vasallo nace de las propias diferencias territoriales, y su origen en los contratos enfitéuticos. Estos continúan incluyendo en la Edad Moderna cláusulas por las que los foreros se comprometen a ser vasallos sirvientes y obedientes, además de una serie de cargas calificadas como señoriales o derechuras a abonar al dueño del dominio directo de la tierra. La superposición a estas del señorío jurisdiccional en el que se entiende como vasallo a aquel sujeto a la jurisdicción de un señor, y señor al que la posee generó un mapa bastante complejo.

En cualquier caso queda patente la diversidad de situaciones. En unos casos cabe hablar de transformación, emulando la forma de actuar de la monarquía y los cambios en el derecho castellano; pero en otros, se aprecia una clara enajenación e innovación de las prerrogativas jurisdiccionales, que si no pasó desapercibida, fue consentida por los monarcas castellanos y sus Audiencias y Chancillerías.

\section{Los oficios señoriales: de los oficiales feudales a los magistrados jurisdiccionales}

\subsection{Alcaldes, merinos y jueces:}

El ejercicio de la jurisdicción plena sobre un territorio, como se ha definido en el apartado precedente, conlleva la asunción por parte de sus señores de las prerrogativas que la monarquía y sus magistrados ejercen en los territorios de realengo -administrativas, gubernativas y judiciales-. Ello hacía necesario un entramado jurídico-administrativo con al menos dos figuras: la justicia y el escribano de señorío o de número. La justicia asumía la presidencia de los concejos y era la máxima autoridad sobre el territorio en materia administrativa y gubernativa. Mientras que los escribanos numerarios ejercían su oficio, adscritos a la jurisdicción o juzgado para el que eran nombrados, y en ella les correspondía privativamente dar fe en todas las intervenciones de los jueces ordinarios. No obstante, estos escribanos debían ser aprobados por la Corona para el ejercicio de su oficio. Correspondía por lo tanto a esta el control último sobre los oficiales encargados de la labor registral.

En los señoríos gallegos bajomedievales la justicia recae en varios oficiales feudales: alcaldes, jueces y merinos. Documentar qué oficiales desempeñaban la función de jus-

62 ARG, Real Audiencia, leg. 17.292, núm. 6, s.f. 
ticia, desde cuándo y cuáles eran sus funciones es mucho más difícil, ya que la mayor parte de la documentación conservada tiene un carácter económico, y la presencia de estos es muy escasa.

A finales del siglo XV el territorio gallego aparece gobernado desde un gran número de fortalezas, desde las que los escuderos e hidalgos administran el territorio a su cargo, sea suyo o de otro señor, bajo el título de alcaldes o merinos. Esta administración se produce en virtud de las relaciones feudales existentes entre las familias y las casas, ya manifestadas por Vasco de Aponte, y siguiendo la tradición medieval de prestar pleito y homenaje al señor, que observamos todavía en 1481, cuando Fernando de Camba se hace cargo de la fortaleza de Arcos (Lugo), que era del conde de Ribadavia - por citar alguno de los ejemplos más tardíos- ${ }^{63}$. Posteriormente con el paso a la modernidad, este tipo de relaciones cambian, con el alejamiento de los grandes señores del territorio gallego, y el establecimiento de una red administrativa moderna, que varía según los casos. En el señorío de Ribadavia, cuando doña María de Moscoso toma la posesión por su hija doña Leonor Sarmiento, encontramos ambas situaciones: mientras en Avión la fortaleza está en manos de un hidalgo, Diego Lunar, que hace pleito homenaje; en Castro Cavadoso hay un merino, Baltasar Salgado, al que se le da la posesión mediante la entrega de la vara de justicia ${ }^{64}$, al igual que en la jurisdicción de Roucos ${ }^{65}$.

De la documentación consultada se percibe que jueces, alcaldes y merinos no debían desarrollar las mismas funciones durante el período medieval en los señoríos donde se ubicaban -como denota la presencia simultánea de alcaldes junto a jueces y merinos ${ }^{66}$ Tampoco ejercen las mismas funciones de un señorío a otro. Esto se hace evidente en el caso de los alcaldes de las ciudades - con unas funciones judiciales mejor documentadas- que se contraponen a los que se encuentran al cargo de la fortaleza del señor en sus tierras. Estos segundos alcaldes funcionarían como representantes del señor en el señorío -y aunque sus funciones nos son desconocidas, parece que asumen aquellas más puramente administrativas y de gobierno-. En el caso de Ribadavia, estos alcaldes pertenecen en muchos casos a la baja nobleza, se trata por tanto de hidalgos y escuderos, que juraban pleitesía al señor y por él administraban y gestionaban el señorío ${ }^{67}$. Por otro lado, jueces y merinos parecen poseer funciones más puramente judiciales, aunque la presencia conjunta de ambos en una misma jurisdicción parece indicar alguna diferencia. Probablemente los merinos -a imitación de los reales- acumulaban capacidades judiciales y administrativas, como recaudadores de rentas del señor. Un

63 Fernández SuÁrez, La nobleza gallega entre los siglos XIV-XV: los Sarmiento condes de Ribadavia, p. 503.

64 Fernández Suárez, Os condes de Ribadavia durante o reinado de Felipe II: estudio e colección documental, pp. 220-221.

65 Fernández Suárez, Os condes de Ribadavia durante o reinado de Felipe II: estudio e colección documental, pp. 226-227.

66 Así se documenta en los señoríos de los Biedma en el XIV y en los de Ribadavia. Fernández OxeA, Descripción de los estados de la Casa de Monterrey en Galicia, p. 94.

67 Fernández SuÁrez, Os condes de Ribadavia durante o reinado de Felipe II: estudio e colección documental, pp. 220-227. 
buen ejemplo se encuentra en el coto de Lobás, cedido por concordia y foro al conde de Lemos en el siglo XVI, en el que además del juez nombrado por el conde como señor, Antealtares - propietario del dominio solariego- se reservó el derecho a nombrar un merino que recaudase y pudiese conocer de todos los pleitos relativos a sus rentas ${ }^{68}$. En los dominios del conde de Lemos, en Belesar, es en uno de los primeros lugares donde documentamos la presencia de un juez nombrado por un señor laico, en $1395^{69}$. Paralelamente a este, encontramos dos alcaldes de la villa de Chantada nombrados por el concejo de vecinos ${ }^{70}$. En 1408 se documenta a Xoán Fernández de Roa, alcalde mayor de Monforte, nombrado por el conde don Fadrique, actuando como juez en un conflicto entre el monasterio de Ferreira de Pantón y sus colonos. En esa misma villa es alcalde Alfonso Ares por el conde de Lemos ${ }^{71}$.

En el señorío de los Biedma, en la provincia de Ourense, Soto Bermud en 1418 está bajo la autoridad del merino de Limia (Juan Martiz), y con él un alcalde privativo de Soto Bermud (Arias Pérez) y dos jueces (Juan Pérez y Domingo Pérez). Con el tiempo, como en el resto de señoríos de Monterrey, la figura del alcalde desaparecerá, quedando al frente la jurisdicción un juez denominado corregidor, junto al escribano de número ${ }^{72}$. Todos sometidos al alcalde mayor de Monterrey.

En el coto monástico de San Esteban de Ribas de Sil en 1488 encontramos dos figuras diferenciadas: un merino, Roi Mosquera, y un juez, Roi Cortés ${ }^{73}$. Además debemos indicar que este monasterio, ya en 1486, ponía juez en el coto de Sobradelo de Limia. El cambio que se produce en lo referente a estos oficiales es seguramente el más determinante para marcar el paso definitivo de un señorío medieval a una jurisdicción moderna. Entonces, la figura se estandariza en un único oficial, que en el territorio sobre el que su señor posee jurisdicción, administra justicia. Es por tanto un delegado del señor, que encarna en sí la jurisdicción enajenada por este al rey. La multiplicidad y dispersión de jurisdicciones de los grandes señores, el absentismo de la Alta Nobleza y el establecimiento de la Real Audiencia en Galicia dan lugar a la aparición de una segunda figura, la del juez de apelaciones señorial; generalmente denominado alcalde mayor, podía conocer en grado de apelación todas las causas pertenecientes al Estado de su señor ${ }^{74}$. Se produce por tanto una especialización evidente, que culmina en el transcurso de la Modernidad con la inhabilitación de los jueces para recaudar rentas en su juzgado.

\footnotetext{
${ }_{68}$ Pousa Diéguez, El señorío de Lobás en la Edad Moderna, pp. 37-46.

69 Méndez Pérez, Otero Piñeiro Maseda y Romaní Martínez, El monasterio de San Salvador de Chantada. Historia y documentos, p. 413.

70 Méndez Pérez, Otero Piñeiro Maseda y Romaní Martínez, El monasterio de San Salvador de Chantada. Historia y documentos, pp. 418 y 424.

71 Fernández Viana Vieites, Colección diplomática del monasterio de Santa María de Ferreira de Pantón, p. 128 .

72 AGS, CE, RG, lib. 224, ff. 361-362.

73 Duro Peña, El monasterio de San Esteban de Ribas de Sil, p. 415.

74 SAaVedra Fernández, "La administración señorial en la Galicia Moderna”, pp. 185-212.
} 
En general, la aparición de jueces en el sentido moderno del término es bastante tardía en el territorio gallego. En Orcellón por ejemplo en 1415 la jurisdicción continúa en manos del monarca ${ }^{75}$, y los diversos señores que en ella tienen sus dominios no han comenzado a nombrar sus propios justicias, como sí lo harán en el XVI -es el caso de don Sancho Sánchez de Ulloa, la encomienda de Pazos de Arenteiro y los monasterios de Oseira, Lobás y Dozón-.

El caso del señorío compostelano constituye una salvedad, ya que en la ciudad de Santiago las pugnas entre concejo y arzobispo hacen que la figura de los alcaldes se desarrolle de forma muy temprana. El propio Alfonso X la había definido ya en 1261, en el transcurso de un pleito entre el concejo y el arzobispo, dando lugar a una justicia mucho más cualificada que los jueces foreros que existían hasta entonces ${ }^{76}$. La mitra compostelana -con el Estado señorial más extenso de Galicia- tendió a reproducir en el resto de núcleos este esquema -Padrón, Muros, Noia, Rianxo, etc. $-^{77}$. La villa de Noia, disponía ya en 1226 de un juez por el rey y el arzobispo ${ }^{78}$. Menos claridad hay en torno al nombramiento de jueces en los señoríos más puramente rurales, como los cotos de Luou o Villestro, donde se documentan jueces señoriales, denominados como tales ya en 1447, que no parecen mostrar muchas diferencias frente a los modernos ${ }^{79}$.

En otros señoríos como el del monasterio de Lobás, el uso de esta prerrogativa jurisdiccional es muy tardío. En 1532 se nombra el primer merino documentado de Lobás, y en 1535 lo documentamos actuando como administrador del territorio, distribuidor de los tributos reales y nombrando al alcalde de hermandad para su cobranza ${ }^{80}$.

Pese a todo, no en todos los territorios bajo dominio señorial, los señores consiguieron imponer a sus propios jueces y apropiarse la jurisdicción sobre la tierra. En este sentido, las parroquias de Melias, Ribela y Coles y el coto de See componen un espacio señorial bastante peculiar. Pertenecientes al monasterio de San Esteban y al Arcediano de Búbal, nunca llegaron a ejercer jurisdicción alguna sobre sus dominios, solo el conde Lemos consiguió alguna. Los condes de Lemos nombraban un juez que administraba justicia, pero el gobierno político y administrativo -recaudación, cumplimiento de órdenes de la cabeza de provincia, reparación de caminos- correspondía a un juez electo por los vecinos hasta el fin del A. R. ${ }^{81}$.

Esto es algo que sucede también en los cotos de la Orden de Santiago, en donde esta nunca llegó a nombrar jueces, y al menos en la Edad Moderna fueron los vecinos los que elegían por sí mismos al juez ${ }^{82}$; y también en algunas de las pequeñas jurisdicciones

\footnotetext{
75 Fernández Viana Vieites, Colección diplomática do mosteiro de San Pedro de Vilanova de Dozón, p. 191.

76 López Díaz, Señorío y municipalidad: convergencia y conflicto de poderes en la ciudad de Santiago, p. 47.

77 López Díaz, Señorío y municipalidad: convergencia y conflicto de poderes en la ciudad de Santiago, pp. 22-30.

78 Pérez Rodríguez, Os documentos do Tombo de Toxosoutos, p. 646.

79 Otero Piñeiro Maseda, Colección diplomática do mosteiro cisterciense de Santa María de Oseira (Ourense), p. 108.

${ }^{80}$ AHPOU, Clero, Caja 10.204, ff. 628-629.

81 AGS, CE, RG, lib. 228, ff. 212-214.

82 AGS, CE, RG, lib. 228, ff. 244-245.
} 
de realengo, como el concejo de Burón que en su ordenamiento de 1526 reafirmaba su capacidad para elegir juez y darle vara de justicia en nombre del rey ${ }^{83}$. Esto muestra la pervivencia de los jueces foreros o vecinales de los concejos rurales y urbanos medievales.

\subsection{De los primeros notarios señoriales a los escribanos de número}

La institución notarial fue objeto de regulación por los monarcas desde las primeras compilaciones. El Fuero Real dedicaba, a comienzos del siglo XIII, un capítulo con siete artículos legislativos dedicados a los escribanos públicos. Alfonso X en las Partidas y el Espéculo estableció la obligación del escribano de conservar la minuta o nota de todos los asuntos escriturados ante é ${ }^{84}$. A este mismo siglo los registros notariales más antiguos localizados -de 1392 en Andalucía y de 1397 en Asturias ${ }^{85}$-.

Fueron los Reyes Católicos los que por la pragmática de 1503 regularon de forma más definitiva la institución notarial, tal y como se recoge en el capítulo XXIII del libro X de la Novísima Recopilación. A esta se añadirá la legislación aportada durante el reinado de Carlos I que incidirá fundamentalmente en aspectos económicos y físicos -acerca de la preservación de las escrituras-.

El derecho a nombrar escribanos y notarios fue en origen una prerrogativa privativa de la Corona, en tiempos de Alfonso X. Pese a ello, la nobleza castellana comenzó a nombrar sus propios escribanos al menos desde el siglo XIII. Posteriormente, Alfonso XI reconocería este derecho solamente a los que hubiesen gozado de él durante más de cuarenta años o gozasen de privilegio expreso, que lo sería de nuevo en las Cortes de Valladolid de $1351^{86}$. Fernando IV es el primero en acceder al nombramiento de escribanos por los señores en las Cortes de Medina del Campo de $1302^{87}$.

El extenso estado de los arzobispos compostelanos podría haber sido de los primeros no solo de Galicia, sino de la Corona Castellanoleonesa en ejercer este derecho. En 1212 comienzan a aparecer notarios en las principales villas de su señorío nombrados por el mitrado o el cabildo de Compostela. En 1245 el mismo arzobispo aparece fijando el arancel al que debían ajustar sus salarios dichos oficiales ${ }^{88}$; poniendo de manifiesto la precocidad de la organización del entramado administrativo de la ciudad.

En Lugo, también de señorío episcopal, el obispo ejercería tempranamente el derecho a nombrar a los notarios públicos, que darían fe de las escrituras tanto en la ciudad como en el resto de cotos de su dominio. En 1312 vería confirmado este derecho por

\footnotetext{
83 García Oro y Portela Silva, La Casa de Altamira durante el Renacimiento, p. 235.

84 Obra Sierra, "Los registros notariales castellanos", pp. 73-111.

85 Marchant Rivera, "La expedición del documento notarial castellano en el tránsito a la Modernidad: de la nota registral a la matriz del protocolo notarial", p. 331.

86 Riesco Terrero, "El notariado castellano Bajomedieval (siglos XIV y XV): Historia de esta institución y de la producción documental de los notarios hasta el reinado de Isabel I de Castilla”, p. 178.

87 Pardo Rodríguez, Señores y escribanos: el notariado andaluz entre los siglos XIV y XVI, p. 25.

88 VÁzQuez Bertomeu, Notarios, notarías y documentos en Santiago y su tierra en el siglo XV, pp. 17-24.
} 
sentencia regia, al reconocer su derecho privativo a nombrar todos los oficios públicos, como señor de la ciudad. Estos escribanos evolucionarían hasta conformarse en los cinco numerarios que llegan al XVI: dos adscritos a la audiencia del alcalde mayor, 2 a la de los alcaldes y el de concejo ${ }^{89}$.

En el resto de señoríos gallegos, la apropiación de este derecho se documenta más o menos a inicios del siglo XIV. Los primeros ejemplos pertenecen al señorío laico más importante de Galicia, el de los condes de Lemos. En 1309, uno de los primeros fue nombrado por don Alfonso, hijo de don Fernando de la Cerda ${ }^{90}$. En 1310 se documenta a otro notario público en Lemos, Pero Fernández, actuando mediante tenientes en Ferreira $^{91}$. En 1310 Martín Fernández es notario e no ledayro de Ferreira polo muy noble señor don Alfonso, fillo del infante don Fernando ${ }^{92}$. A mediados de siglo, en 1355, Alfonso González es notario en Val de Ferreyra por Roy Garçía, notario público en Llemos polo conde don Enrique ${ }^{93}$, y actúa como tal hasta 1359.

La sucesión de varios escribanos en un mismo territorio plantea varias cuestiones, de momento sin respuesta: ¿cuál era la duración de los empleos? ¿Eran vitalicios o hereditarios? y ¿Qué número de escribanías numerarias fueron creadas? ¿Fue la apropiación de este derecho limitada o controlada de algún modo por la Corona y sus oficiales?

Sea como fuere, los escribanos de número documentados y el amplio territorio sobre el que ejercen su oficio -de acuerdo a su intitulación-muestran un número de notarios muy inferior a los de Época Moderna, en que se documenta al menos uno por cada jurisdicción de la Casa de Lemos (Monforte, Chantada, Caldelas, etc.) En el siglo XIV parecen ser nombrados como notarios de todo el señorío, ejerciendo el oficio mediante tenientes en los distintos lugares.

Durante todo este período el monasterio de Ferreira de Pantón carece de notarios propios. En 1372 Alfonso González ejerce en sus tierras como notario del Val de Ferreira nombrado por el conde don Pedro ${ }^{94}$. Solo en algunos documentos -forales fundamentalmente-, aparecen de forma paralela actuando como notarios del monasterio por las mismas fechas algunos clérigos: como Pero Yanes, intitulados como escribanos polo dito mosteiro $^{95}$. Pese a ello, la Casa de Lemos continúa nombrando escribanos de número que

\footnotetext{
89 FERNÁNDEZ SuÁREZ, "Una primera aproximación a los escribanos del concejo de Lugo entre los siglos XVI y XVIII", pp. 145-147.

90 "teente as vezes en Val de Ferreyra de Miguel Martiis, notario por don Affonso en Lemos". Fernández Viana Vieites, Colección diplomática del monasterio de Santa María de Ferreira de Pantón, p. 49.

91 Fernández Viana Vieites, Colección diplomática del monasterio de Santa María de Ferreira de Pantón, p. 51.

92 Lucas Álvarez, El priorato benedictino de San Vicenzo Pombeiro y su colección diplomática en la Edad Media, p. 49.

93 Fernández Viana Vieites, Colección diplomática del monasterio de Santa María de Ferreira de Pantón, p. 77.

94 Fernández Viana Vieites, Colección diplomática del monasterio de Santa María de Ferreira de Pantón, p. 85 .

95 Fernández Viana Vieites, Colección diplomática del monasterio de Santa María de Ferreira de Pantón, p. 90 .
} 
actúan en el coto de Pantón: en 1382 Mateo González es el nuevo notario de Ferreira nombrado por el conde don Pedro ${ }^{96}$; en 1399 Ares Afonso es el notario público en os coutos de Pantón por Pero Diao de Cadórnega ${ }^{97}$; en 1401 Fernán Falaco figura como notario público del Val de Ferreira por el conde don Fadrique ${ }^{98}$. A partir de 1402 este último actúa paralelamente en la zona junto a Ares Fenández y Pero Alfonso de Moreda (desde 1410), nombrados por Pedro Díaz de Cadórniga y García Díaz de Cadórniga ${ }^{99}$. En las tierras del monasterio de Ferreira de Pantón y de Pombeiro -en medio del señorío de los Lemos- no se documentan notarios propios de dichos monasterios; sino, solo por los diversos condes de Lemos hasta finales del siglo XV. Todos con un ámbito de actuación territorial muy amplio ${ }^{100}$; a los que se añaden los nombrados por los Cadórniga ya en el siglo XV. En 1429 aparece el maestro Juan como notario público en los cotos de Pantón por doña Beatriz, mujer de García Díaz de Cadórniga, actuando paralelamente a Gonzalo Pérez de Eiré ${ }^{101}$.

En la villa y tierras de Chantada, hasta 1395, los notarios figuran como notarios públicos en Chantada y su alfoz. Alfonso de Deus es el primero en figurar intitulado como notario público en o couto de Belsar et em todo o condado por o conde dom Pedro, condeestavel em Castella ${ }^{102}$. En 1418 Iohan Fernández de Gonte aparece como notario publico e no reyno de Galiza por noso señor el rey et en terras de Saviñao et Sardiñeiros por noso señor o conde don Fadrique ${ }^{103}$. En 1457 encontramos la primera referencia a un notario de Monforte nombrado por los condes, y cuyo oficio se limita a esta villa y su jurisdicción ${ }^{104}$. Lo mismo sucede con Gomes Peres, notario público de Chantada y su alfoz en $1496^{105}$.

96 Fernández Viana Vieites, Colección diplomática del monasterio de Santa María de Ferreira de Pantón, p. 92.

97 Fernández Viana Vieites, Colección diplomática del monasterio de Santa María de Ferreira de Pantón, p. 104.

98 Fernández Viana Vieites, Colección diplomática del monasterio de Santa María de Ferreira de Pantón, p. 107.

99 Fernández Viana Vieites, Colección diplomática del monasterio de Santa María de Ferreira de Pantón, pp. 112-138.

100 Pero Alfonso, aparece como notario por el conde don Fadrique a partir de 1412 tanto en tierra de Ferreira como de Pombeiro hasta 1424 en que lo sustiuye Gonzalo Perez de Eiré. En 1432 Rodrigo Buján es notario por el señor don Fadrique "en todo o seu condado e terras e señoríos". Más adelante en la misma tierra aparece actuando Álvaro Alfonso "criado de Afonso Lopez de Lemos et de Valboa e seu notario publico en todos los seus coutos e terras e senoryos. Fernández Viana Vieites, Colección diplomática del monasterio de Santa María de Ferreira de Pantón, pp. 143, 182 y 199.

101 Fernández Viana Vieites, Colección diplomática del monasterio de Santa María de Ferreira de Pantón, p. 194.

102 Fernández SuÁrez, La nobleza gallega entre los siglos XIV-XV: los Sarmiento condes de Ribadavia, p. 413.

103 LuCas Álvarez, "Notariado y notarios en el monasterio de Pombeiro", p. 48.

104 Lucas Álvarez, "Notariado y notarios en el monasterio de Pombeiro", p. 52.

105 Fernández SuÁrez, La nobleza gallega entre los siglos XIV-XV: los Sarmiento condes de Ribadavia, p. 424. 
Hacia 1435 comienzan a figurar en la documentación notarios diferentes para la villa de Monforte y el resto de tierras de Lemos - como es el caso de Lope Vázquez notario de Monforte por el conde y Alfonso Conde en Ferreira, Eiré y Pantón- ${ }^{106}$. En 1458 Álvaro García de Eiré es notario por el conde de Lemos en Monforte, mientras Álvaro Fernández de San Cosmede lo es enna administración do Val de Ferreira et couto dEyree et dos coutos de Pantón ${ }^{107}$.

En tierras de Monterroso y Repostería, dominio de los Ulloa, solo se documentan notarios reales desde la segunda mitad del siglo XIV. En 1355 Alonso Pérez es el primer notario pollo conde don Enrique en na or de Monterroso ${ }^{108}$.

En los señoríos de los Andrade disponemos de notarios nombrados por los señores al menos desde 1410. En esa fecha Domingo Afonso se intitula notario público en Ferrol por Nuño Freire D'andrade ${ }^{109}$.

De igual modo en el Sur de Ourense bajo el señorío de los Biedma, estos señores nombran sus propios escribanos al menos desde el primer cuarto del s. XV. En la jurisdicción de Soto Bermúd, documentamos notarios ya en 1418 -Miguel Rodríguez en terra de Velada, notario publico por Juan Rodríguez de Viezma e pelo poder y actoridad de lo dito Juan Rodríguez me deu en terra de Soutovermud ${ }^{110}{ }_{-}$.

San Salvador de Celanova, el monasterio benedictino que en la Edad Moderna contará con un señorío jurisdiccional más extenso ${ }^{111}$, parece ser de los más precoces en lo que toca al nombramiento de escribanos y notarios propios. Pese a la frecuente actuación de monjes del monasterio como escribanos, estos manifiestan su condición de notarios públicos del monasterio. Ya en 1272 Stephanus Iohanis figura como monachus, publicus notarius ${ }^{112}$, en 1298 Johan Eanes como monge notario ${ }^{113}$, y en 1304 Johan Peres se intitula ya notario de Cellanova por o abade ${ }^{114}$. No obstante, el que en 1333 este monje se haya convertido en abad muestra que el oficio no dejaba de ser uno más dentro de la comunidad monástica, sin cumplir la función más allá de los muros del monasterio. Hay que esperar a 1344 para encontrar un notario nombrado por el abad en tierra de Soutobad y Eiré, que cumpla la función de un escribano señorial en tierras del monasterio ${ }^{115}$.

\footnotetext{
106 Fernández Viana Vieites, Colección diplomática del monasterio de Santa María de Ferreira de Pantón, pp. 207 y 215.

107 Fernández Viana Vieites, Colección diplomática del monasterio de Santa María de Ferreira de Pantón, pp. 239-240.

108 Rey Caíña, Colección diplomática de Ferreira de Pallares, p. 1.062.

109 Correa Arias, A casa de Andrade 1160-1540, p. 623.

110 Fernández Oxea, Descripción de los estados de la Casa de Monterrey en Galicia, p. 94.

111 SaAvedra Fernández, "Los señoríos de las grandes órdenes monásticas en la Galicia Moderna: una visión Global”, pp. 277-280.

112 Vaquero Díaz, Colección diplomática do mosteiro de San Salvador de Celanova (ss. XII-XV), p. 107.

113 Vaquero Díaz, Colección diplomática do mosteiro de San Salvador de Celanova (ss. XII-XV), p. 133.

114 Vaquero Díaz, Colección diplomática do mosteiro de San Salvador de Celanova (sS. XII-XV), p. 134.

115 Vaquero Díaz, Colección diplomática do mosteiro de San Salvador de Celanova (ss. XII-XV), p. 189.
} 
Al monasterio de Celanova se suma el de San Esteban de Ribas de Sil, que dispone de notarios propios desde la segunda mitad del siglo XIV. En 1360, Gonzalo Eanes figura como notario jurado et publico en no dito couto do moesterio de santo Estevo de Riba de Sil por el rey et por el moesteiro sobredito de Santo Estevo et abbade desse lugar ${ }^{116}$. $\mathrm{Y}$ en 1405 Johan Seoane nuevamente notario público no couto de Santo Estevo de Ribas de Sil por el rey e pollo mosteiro e abade ${ }^{117}$.

Entre las colecciones documentales revisadas de otros monasterios benedictinos gallegos como Chantada, Lobás o Dozón; Celanova parece ser el único en usar este privilegio tan tempranamente. Lucas Álvarez constató que algunos monasterios como Sobrado o Ramirás desarrollaron tempranamente la figura de un escribano de cabildo, no así Samos $^{118}$. ¿Pero actuaban estos como notarios señoriales dando fe a los documentos de los vasallos de su término?

En la documentación del monasterio cisterciense de Oseira -uno de los principales junto a Sobrado- no se documenta la intervención de ningún escribano señorial como tal en las escrituras otorgadas por el abad, sino que son redactadas en su mayoría por varios monjes, que rara vez se intitulan como escribanos o notarios, por lo que no parece haberse desarrollado si quiera la figura de notario capitular ${ }^{119}$.

No obstante, la figura del escribano no solo parece no adquirir entidad propia para el monasterio, sino que en la segunda mitad del siglo XV se enrarece, figurando en ocasiones alguno entre los testigos, pero sin constar el redactor del documento ${ }^{120}$. Ello denota la poca importancia dada por la Oseira a que los documentos -fundamentalmente contratos enfitéuticos- contasen con el respaldo de un escribano o notario público.

Caso aparte son los señoríos episcopales. La iglesia llevaba mucho adelantado en lo que a los notarios apostólicos refiere. Entre 1167 y 1169 Alejandro III había regulado la actividad notarial mediante el decreto Scripta Authentica ${ }^{121}$.

En la ciudad de Santiago, Alfonso X movido por los pleitos entre el arzobispo y el Concejo dicta una sentencia arbitral, en 1263, por la que quedará regulado el nombramiento de notarios de la ciudad, que debían ser dos eclesiásticos y dos legos, debían ser omes buenos y no paniaguados del arzobispo ${ }^{122}$.

\footnotetext{
116 Lucas Álvarez, El priorato benedictino de San Vicenzo Pombeiro y su colección diplomática en la Edad Media, p. 47.

117 Duro Peña, El monasterio de San Esteban de Ribas de Sil, p. 336.

118 Lucas Álvarez, "El notariado en Galicia hasta el año 1300 (una aproximación), Notariado público y documento privado: de los orígenes al siglo XIV", pp. 354, 356 y 358.

119 Frey Johan (vestiario), frey Gonçalvo eanes, frey Gonçalvo de Camba, etc. Colección diplomática do mosteiro cisterciense de Santa María de Oseira (Ourense).

${ }^{120}$ Colección diplomática do mosteiro cisterciense de Santa María de Oseira (Ourense).

${ }^{121}$ Lucas Álvarez, "El notariado en Galicia hasta el año 1300 (una aproximación), Notariado público y documento privado: de los orígenes al siglo XIV", p. 342.

122 LuCas Állvarez, "El notariado en Galicia hasta el año 1300 (una aproximación), Notariado público y documento privado: de los orígenes al siglo XIV", p. 347.
} 
En el resto de jurisdicciones de la mitra de Santiago, el nombramiento de notarios señoriales es muy temprano. En 1212 se documenta al primero de Padrón, siguiéndole otros ejemplos en Pontevedra (en 1223) y Muros ${ }^{123}$. En 1334, Johan Afonso figura ya -en una jurisdicción separa como era el coto de Loio- como notario publico de Portomarín et do couto de Loyo polo señor arçebispo ${ }^{124}$. De igual modo, la jurisdicción de Noia contaba con su propio escribano señorial en la Baja Edad Media. En 1487, Fernando Afonso de Betanços era escrivano de Cámara del rey e reyna nuestros señores e notario público jurado da vyla de Noya por la iglesia de Santiago ${ }^{125}$.

En la ciudad de Ourense, la carta puebla de doña Urraca, concediendo el señorío de la ciudad al obispo recogía ya el derecho de nombramiento de cargos públicos; aunque en 1257 Alfonso X debe intervenir ante las quejas de los vecinos contra el escribano mayor, denominado Chanceller que nombraba el obispo; quedó regulado dicho nombramiento por tanto desde la segunda mitad del siglo XIII. Por recoger algún ejemplo, en 1357 Pedro Fernández figura como notario publico d'Ourense polla iglesia desse lugar ${ }^{126}$.

En el caso del obispo de Lugo, señor de aquella ciudad, comienza a nombrar escribanos desde el siglo XIII. El privilegio de Sancho IV de 1295 le concedía este derecho, además de el de nombrar alcaldes. Entre 1312 y 1333, aparece en Ferreira de Pallares el escribano Vasco Fernández como notario publico jurado pelo obispo de Lugo en terra de Pallares et no couto de Ferreyra ${ }^{127}$. Cabe señalar que este coto es señorío del monasterio de Samos en la Edad Moderna, en el que pone juez y otros oficiales ${ }^{128}$. Este privilegio fue conservado al menos hasta 1513, cuando es escribano del coto de Ferreira por el obispo de Lugo ${ }^{129}$, anexionado en 1517 al de San Salvador de Samos.

Los ejemplos anteriores muestran una cronología bastante temprana en la enajenación de la regalía de nombrar escribanos. Pero hubo situaciones inversas, en las que los señores no comienzan a nombrar escribanos en sus jurisdicciones hasta finales del siglo XVI. Es lo que sucede en la antigua merindad de Orcellón en el Noroeste orensano. En el siglo XVII las jurisdicciones de Orcellón, Castro Cavadoso, Pazos de Arenteiro, Lobás y Dozón disponen cada una de su propio escribano numerario, nombrado por el señor -que lo eran los condes de Monterrey, los condes de Ribadavia, la Orden de San Juan y el monasterio de Antealtares, respectivamente-. En la primera mitad del siglo XVI, toda la tierra de Orcellón y de Dozón disponía de un mismo escribano de número, que se intitulaba a sí mismo notario publico por noso señor el rey e tierra de Orzellón e de Deçon ${ }^{130}$. Esto podría explicarse porque estas tierras formaban parte en el siglo XIV de la misma merindad, denominada de Orcellón, que rebasaba los límites

\footnotetext{
${ }_{123}$ VÁzquez Bertomeu, Notarios, notarías y documentos en Santiago y su tierra en el siglo XV, p. 12.

124 Rey Caíña, Colección diplomática de Ferreira de Pallares, p. 964.

${ }^{125}$ ARCHV, Pergaminos, Car. 159, 1 y 2.

126 Fernández Fernández, O mosteiro feminino de San Miguel de Bóveda, p. 143.

127 Rey Caíña, Colección diplomática de Ferreira de Pallares, p. 865.

128 AGS, CE, RG, lib. 174, f. 5.344.

129 ReY CAíña, Colección diplomática de Ferreira de Pallares, p. 1333.

${ }^{130}$ Fernández SuÁrez, La nobleza gallega entre los siglos XIV-XV: los Sarmiento condes de Ribadavia, p. 427.
} 
de la maestrescolía del mismo nombre. Hasta ese momento todos los notarios públicos documentados eran escribanos reales, sin adscripción ni nombramiento especial de ningún señor, intitulados escribanos del rey -Pedro Leal en $1315^{131}$, Juan Martínez en $1334^{132}$, y Alfonso Fernández ${ }^{133}-$, y notarios jurados ${ }^{134}$ y excusadores ${ }^{135}$ por estos, actuando también sobre Castela, Bolo de Senda y Búbal. Duro Peña ya había indicado cómo Pedro Fernández (1312-1317) y Fernando Pérez (1318-1320) figuraban como notarios jurados en la tierra de la merindad de Orcellón ${ }^{136}$. Por su parte, en el coto de Lobás no se nombran escribanos de número del coto hasta después de su reintegración al monasterio de Antealtares en $1621^{137}$.

La aparición de escribanos y notarios que manifiestan en su intitulación y en los documentos que otorgan, que ejercen el oficio de tales con algún tipo de autorización o nombramiento de los señores de esas tierras, da cuenta de dos hechos muy relevantes: la definición de las tierras bajo el dominio de un señor como un señorío jurisdiccional - como lo define Castillo de Bovadilla-, y la consecuente necesidad de contar con la autorización de estos señores para ejercerlo en ellas. El otorgamiento de escrituras se veía pues respaldado por el señor, envestido del poder jurisdiccional y de la justicia, enajenados de la Corona. Por tanto, la aparición de estos escribanos señoriales podría utilizarse como un indicador más en los territorios de señorío, para datar su evolución de un señorío puramente feudal hacia la jurisdicción moderna.

\section{Cambios en el mapa jurisdiccional entre los siglos XV y XVI}

A diferencia de lo que sucede en los señoríos jurisdiccionales modernos que no pueden ser objeto de división, hasta su configuración definitiva como tales, los señoríos feudales gallegos están sujetos a diversos cambios: pasando por la fragmentación -generada y favorecida por el sistema hereditario, hasta la plena instauración del mayorazgo- o la fusión de espacios que tenían un origen diferente.

Un ejemplo de fusión de espacios originariamente diferentes lo encontramos en la Encomienda de Pazos de Arenteiro, de la Orden de San Juan. En origen, a ella pertenecían dos espacios o señoríos separados y diferentes: el coto de Cusanca -procedente de una donación- y la jurisdicción de Pazos, que a lo largo del XVI se fusionan pasando a conformar un todo sobre el que la Orden y sus comendadores ejercen el mismo tipo de prerrogativas jurisdiccionales. Las fusiones de territorios diferentes se vieron favore-

\footnotetext{
131 AHN, Clero, Car. 1.541, núm. 13.

132 AHN, Clero, Car. 1.545, núm. 10.

133 AHN, Clero, Car. 1.545, núm. 16.

134 Alfonso Eanes, en 1315, notario jurado en tierras de Castella, Búbal y Bolo de Senda por Pedro Leal, notario del rey en la merindad de Orcellón. AHN, Clero, Car. 1.541, núm. 13.

135 Alfonso Eanes «escusador» en Bolo de Senda y Dozón, por Alfonso Fernández notario del rey en la merindad de Orcellón. AHN, Clero, Car. 1.545, núm. 16.

136 Duro Peña, "El monasterio de San Pedro de Lobanes”, p. 329.

137 AHPOU, Clero, Caja 10.206, ff. 230-236.
} 
cidas también por el sistema de encomiendas y tenencias, que dan lugar a numerosos pleitos durante el siglo XV y el XVI. Otro caso de fusión de espacios originariamente diferentes lo encontramos en la jurisdicción de Orcellón, conformada en origen por dos cotos separados Xubencos y Loureiro, tal y como se contiene en el testamento de Gonzalo Ozores, en el siglo XVI conforman una jurisdicción con el nombre de la antigua merindad y arcedianato donde se ubicaba ${ }^{138}$, a las que se suman en 1441 las feligresías de Cameixa, Brués y Xendive por donación del conde de Ribadavia.

En los Estados de la Casa de Ribadavia encontramos también numerosos cambios en el territorio entre el siglo XV y el XVIII. El coto de Laias que en 1480 constituye una jurisdicción independiente ${ }^{139}$ pasa a conformar más adelante parte de la amplia jurisdicción de Maside $^{140}$, que en 1573 figura en la documentación también como un coto independiente ${ }^{141}$. De un modo semejante, la jurisdicción de Castro Cabadoso en el noroeste orensano nace de la fusión de varios cotos pertenecientes a los condes de Ribadavia ${ }^{142}$. El coto de San Cristóbal de Cristimil, en las cercanías de la ciudad de Ourense había sido donado por Fernando II al monasterio de San Esteban ${ }^{143}$, no obstante en la Edad Moderna pasa a formar parte de una jurisdicción mucho más amplia -compuesta por las parroquias de Armariz, Siabal Tibiás, Sabadelle, Moreiras, Medorra, Prexigueiro, Calvelle, etc.- con su cabeza en Pereiro de Aguiar y pertenecientes al Marqués de Malpica ${ }^{144}$. Se desconoce en qué momento se produjo el traspaso entre el monasterio y los condes de Benavente, pasando a través del matrimonio de José Pimentel Zúñiga, hijo del conde de Benavente, con doña Francisca Zúñiga, en el siglo XVII. Son varios los casos en los que detectamos los intentos de los monasterios por concentrar sus posesiones en sus cotos y espacios cercanos, como son los de Lobás ${ }^{145}$, Oseira y Monfero. Este último adquiere de Pedro Bermúdez de Andrade todos los bienes que tenía en su coto con ese fin ${ }^{146}$.

Otro ejemplo, son los cotos de Serramo y Carnes que en el siglo XV pertenecían a Luis Soga de Lobeira por donación de don Pedro, conde de Trastámara, a Diego Alfonso, confirmada por Juan II, y en la Edad Moderna pasan a componer parte de la jurisdicción de Vimianzo perteneciente a la casa de Altamira. Además de estos cotos, los de Conrado y el puerto de Laxe habían sido adquiridos por compra a don Fernán González de Marcelle ${ }^{147}$. La jurisdicción del coto de Oira, cercano a la ciudad de Ourense, también acabó dividida entre los monasterios de Antealtares y Oseira. Esta partición

\footnotetext{
138 Pousa DiÉguez, Conflictividad y poder en la jurisdicción de Orcellón (s. XVIII), pp. 12-25.

139 Fernández SuÁrez, La nobleza gallega entre los siglos XIV-XV: los Sarmiento condes de Ribadavia, 295-297.

140 AGS, CE, RG, lib. 217, ff. 616-617.

141 Fernández SuÁrez, Os condes de Ribadavia durante o reinado de Felipe II: estudio e colección documental, p. 232.

142 Fernández SuÁrez, La nobleza gallega entre los siglos XIV-XV: los Sarmiento condes de Ribadavia, pp.169-177.

143 Duro Peña, El monasterio de San Esteban de Ribas de Sil, p. 251.

144 AGS, Catastro de Ensenada, R. G., lib. 220.

145 Pousa DiéGuez, El señorío de San Pedro de Lobás en la Edad Moderna, 2016.

146 Correa Arias, A casa de Andrade 1160-1540, p. 586.

147 García Oro y Portela Silva, La Casa de Altamira durante el Renacimiento, p. 53.
} 
tiene su origen en la donación de la mitad al monasterio de Oseira por la abadesa de Dozón ${ }^{148}$. Y sobre el que en la Edad Moderna administran justicia mediante un juez ${ }^{149}$. En cuanto al caso inverso, el de la división de espacios, basta acudir a los testamentos y donaciones de la época para constatar la libertad con la que los señores medievales disponían de las tierras de su señorío. Incluso en 1515 doña Teresa de Zúñiga, condesa de Monterrey, y heredera de un vasto señorío procedente del linaje de los Biedma, los Ulloa y los Zúñiga, fragmentó parte de estos dejándolos en herencia a la hija de su segundo matrimonio ${ }^{150}$.

Otro factor que generó ciertos cambios en el mapa señorial gallego fue la reforma monástica promovida por los Reyes Católicos, que hizo que los monasterios como Pinario o Antealtares, a los que se anexionaron muchos monasterios benedictinos masculinos y femeninos, reclamasen el dudoso señorío jurisdiccional sobre las tierras de sus prioratos, como fue el caso del de San Pedro de Lobás ${ }^{151}$. Incluso alcanzado el siglo XVII, el conde de Ribadavia desmiembra de sus dominios ciertas tierras, para conceder dos cotos a dos fieles vasallos ${ }^{152}$.

\section{Conclusiones}

Los señoríos gallegos bajomedievales constituyen una realidad heterogénea y cambiante. Entre los siglos XIV y XVI todos experimentaron una evolución notable de un señorío completamente feudal en su estructura y gestión hacia un señorío jurisdiccional, claramente distinguido del solariego. Independientemente de las cláusulas contenidas en los privilegios en que tuvieron su origen, fueron el devenir histórico, la voluntad de los señores y el consentimiento de los vasallos los que -en la mayoría de casos- modelaron un entramado administrativo tan poco homogéneo. Los señoríos urbanos, y en especial el de los arzobispos de Santiago, fueron los más precoces en la consolidación de las amplias prerrogativas con que alcanzan el siglo XVI, así como en la arrogación del derecho a impartir justicia y nombrar a los distintos oficiales que administraban sus dominios.

Fue un proceso en el que la Corona y sus instituciones se mantuvieron al margen actuando como consentidores de la enajenación de todos esos privilegios por prescripción inmemorial, interviniendo solo en caso de conflicto. A través de sus sentencias -en los casos en que la propiedad del señorío o prerrogativas eran disputadas- reafirmaron el señorío, entregándoles en ocasiones a sus propietarios prerrogativas que originariamente no poseían. Todo ello hace necesario continuar ahondando en el estudio de casos concretos, que irá clarificando la imagen aún borrosa de un fenómeno tan diverso en sus formas y evolución.

\footnotetext{
148 AHPOU, Clero, Caja 10.066, s.f

149 AGS, CE, RG, lib. 215, ff. 330-331.

150 Oliveira Serrano, “Los señores del Estado de Monterrey”, pp. 165-169.

151 Pousa Diéguez, El señorío de San Pedro de Lobás en la Edad Moderna, pp. 25-36.

152 Gallego Domínguez, "Mercedes de los condes de Ribadavia a dos hidalgos de la jurisdicción de Valdeorras", pp. 131-142.
} 


\section{Bibliografía citada}

Ayala Martínez, Carlos, Las órdenes militares hispánicas en la Edad Media, ed. Marcial Pons, Madrid, 2007.

Bermejo Cabrero, José Luis, "En torno a las Cortes de Nájera", Anuario de Historia del Derecho Español, 70 (2000), pp. 245-250.

Bermúdez Aznar, Agustín, El corregidor en Castilla durante la Baja Edad Media (1348-1474), ed. Universidad de Murcia, Murcia, 1974.

Colmeiro Penido, Manuel, Historia de las Cortes de León y de Castilla, Madrid, 1883. Correa Arias, Francisco José, A casa de Andrade 1160-1540, Toxosoutos, Noia, 2009.

Cuadrada Majó, Coral, Poder, producción y familia en el mundo rural catalán (siglo XI-XIV), en Relaciones de poder, producción y parentesco en la Edad Media y Moderna, ed. CSIC Madrid, 1990.

Duro Peña, Emilio, "El monasterio de San Pedro de Lobanes", Compostellanum, 13 (1968), pp. 287-335.

Duro Peña, Emilio, El monasterio de San Esteban de Ribas de Sil, ed. Diputación Provincial de Ourense, 1977.

Duro Peña, Emilio, El monasterio de San Pedro de Rocas y su colección documental, ed. Instituto de Estudios Orensanos Padre Feijoo, 1973.

EIRAs RoEl, Antonio "El señorío gallego en cifras: nómina y ranking de señores jurisdiccionales”, Cuadernos de Estudios Gallegos, 38 (1989), pp. 7-46.

Fernández Oxea, José Ramón, Descripción de los estados de la Casa de Monterrey en Galicia, ed. Cuadernos de Estudios Gallegos, Santiago, 1950.

FERnÁndez SuÁrez, Gonzalo Francisco, "Una primera aproximación a los escribanos del concejo de Lugo entre los siglos XVI y XVIII", Sub Urbem: historia, sociedade e cultura da cidade, Santiago de Compostela, 2012, pp. 143-159.

FERnÁndez SuÁrez, Gonzalo Francisco, La nobleza gallega entre los siglos XIV-XV: los Sarmiento condes de Ribadavia, ed. El Eco Franciscano, Santiago, 2002.

Fernández SuÁrez, Gonzalo Francisco, Os condes de Ribadavia durante o reinado de Felipe II: estudio e colección documental, ed. Toxosoutos, Noia, 2003.

Fernández Viana Vieites, José Ignacio, Colección diplomática do mosteiro de San Pedro de Vilanova de Dozón, ed. Cuadernos de Estudios Gallegos, Santiago de Compostela, 2009.

Fernández Viana Vieites, José Ignacio, Colección diplomática del monasterio de Santa María de Ferreira de Pantón, ed. Diputación Provincial de Lugo, Lugo, 1994.

Fernández Fernández, Adolfo, O mosteiro feminino de San Miguel de Bóveda, ed. Toxosoutos, Noia, 2005.

Ferro Couselo, Xesús, A vida e a fala dos devanceiros, ed. Galaxia, Vigo, 1967. 
Gallego Domínguez, Olga, "Mercedes de los condes de Ribadavia a dos hidalgos de la jurisdicción de Valdeorras”, Boletín Auriense, 31 (2001), pp. 131-142.

García Oro, José La nobleza gallega en la Baja Edad Media: las casas nobles y sus relaciones estamentales, ed. Bibliófilos gallegos, Santiago de Compostela, 1981.

García Valdeavellano Arcimís, Luis “La cuestión del feudalismo hispánico”, El feudalismo hispánico y otros estudios de historia medieval, ed. Crítica, Barcelona, pp. 7-62. García Valdeavellano Arcimís, Luis, Señores y burgueses en la Edad Media Hispana, ed. Real Academia de la Historia, Madrid, 2006.

Grassoti, Hilda, "Dominus y dominum en la terminología jurídica de Asturias, León y Castilla (siglos IX-XIII)”, Anuario de Historia del Derecho Español, 50 (1980), pp. 654-682.

Grasotti, Hilda, "Novedad y tradición en las donaciones con mero y mixto imperio en León y Castilla", Homenaje al profesor Juan Torres Fontes, ed. Universidad de Murcia, Murcia, 1987, pp. 723-736.

GuILARTE ZAPATERo, Alfonso María, El régimen señorial en el siglo XVI, ed. Universidad de Valladolid, Valladolid, 2013.

Hespanha, Antonio Manuel "El espacio político", La gracia del derecho: economía de la cultura en la Edad Moderna, ed. Centro de Estudios constitucionales, Madrid, 1993, pp. 85-121.

López DíAz, María, "La administración de la justicia señorial en el Antiguo Régimen”, Anuario de Historia del Derecho Español, 76 (2006), pp. 557-588.

LóPez DíAz, María, Señorío y municipalidad: convergencia y conflicto de poderes en la ciudad de Santiago, ed. Universidad de Santiago de Compostela, Santiago, 1994.

López Sangil, José Luis, Historia del monasterio de Santa María de Monfero, ed. Diputación Provincial da Coruña, A Coruña, 1999.

LuCAS Álvarez, Manuel, "El notariado en Galicia hasta el año 1300 (una aproximación), Notariado público y documento privado: de los orígenes al siglo XIV", Actas del VII Congreso internacional de Diplomática, ed. Universidad de Valencia, Valencia, 1989, vol. I, pp. 331-480.

LuCAs Álvarez, Manuel, "Notariado y notarios en el monasterio de Pombeiro", Cuadernos de Estudios Gallegos, 40 (1992), pp. 43-61.

Lucas Álvarez, Manuel, El priorato benedictino de San Vicenzo Pombeiro y su colección diplomática en la Edad Media, ed. Do Castro, Sada, 1996.

Marchant Rivera, Alicia, "La expedición del documento notarial castellano en el tránsito a la Modernidad: de la nota registral a la matriz del protocolo notarial", Paseo Documental por el Madrid de Antaño, ed. Universidad Complutense de Madrid, Madrid, 2015, pp. 331-347.

Martínez Salazar, Andrés, Crónica Troyana: códice gallego del siglo XIV, ed. Casa de la Misericordia, Madrid, 1901. 
Méndez Pérez, José, Otero Piñeiro Maseda, Pablo y Romaní Martínez, Miguel, El monasterio de San Salvador de Chantada. Historia y documentos, Santiago de Compostela, ed. Cuadernos de Estudios Gallegos, Santiago de Compostela, 2016.

Moxó Ortiz de Villajos, Salvador, Feudalismo, señorío y nobleza en la Castilla Medieval, ed. Real Academia de la Historia, Madrid, 2000.

Obra SierRA, Juan María "Los registros notariales castellanos", La escritura de la Memoria: los registros, VIII Jornadas de la Sociedad Española de Ciencias y Técnicas Historiográficas, ed. Promociones y Publicaciones Universitarias, Barcelona, 2011, pp. 73-111.

Oliveira Serrano, César "Los señores del Estado de Monterrey", Cuadernos de Historia de España, 80 (2006), pp. 285-315.

Otero PiñeIro Maseda, Pablo, Colección diplomática do mosteiro cisterciense de Santa María de Oseira (Ourense) 1435-1485, ed. Tórculo, Santiago de Compostela, 2008, vol. V.

Pallares Méndez, María del Carmen, "Los cotos como marco de los derechos feudales en Galicia durante la Edad Media (1100-1500)", Liceo Franciscano, 31 (1978), pp. 201-225.

Pardo Rodríguez, María Luisa, Señores y escribanos: el notariado andaluz entre los siglos XIV y XVI, ed. Universidad de Sevilla. Sevilla, 2002.

Pérez Rodríguez, Francisco Javier, Os documentos do Tombo de Toxosoutos, ed. Consello da Cultura Galega, Santiago de Compostela, 2004.

Portela Silva, María José y García Oro, José, La Casa de Altamira durante el Renacimiento, ed. El Eco Franciscano, Santiago, 2003.

Pousa Diéguez, Rodrigo, El señorío de Lobás en la Edad Moderna, ed. Diputación Provincial de Ourense, Ourense, 2016.

Pousa DiÉGuez, Rodrigo, Conflictividad y poder en la jurisdicción de Orcellón (siglo XVIII), Bubok, Madrid.

Rey CAíña, José Ángel, Colección diplomática de Ferreira de Pallares, Universidad de Granada, Tesis doctoral inédita, 1985.

RIEsco Terrero, Antonio, "El notariado castellano Bajomedieval (siglos XIV y XV): Historia de esta institución y de la producción documental de los notarios hasta el reinado de Isabel I de Castilla", II Jornadas Cientificas sobre la Documentación de la Corona de Castilla (siglos XIII-XV), ed. Universidad Complutense de Madrid, Madrid, 2003, pp. 175-225.

Rodríguez Fernández, Justiniano, "Coto de Celanova (Orense) y su fuero", Archivos leoneses, 73 (1983), pp. 83-90.

SaAvedra Fernández, Pegerto, "La administración señorial en la Galicia Moderna", Hispania: Revista Española de Historia, 58 (1998), pp. 185-212. 
Saavedra Fernández, Pegerto, "Los señoríos de las grandes órdenes monásticas en la Galicia Moderna: una visión Global”, Estudios en homenaje al profesor José M. Pérez García, ed. Universidade de Vigo, Vigo, 2004, vol. II, pp. 277-306.

Serrano Martín, Eliseo y Sarasa Sánchez, Esteban, Señorío y feudalismo en la Península Ibérica, ed. Institución Fernando el Católico, Zaragoza, 1993.

UsunÁRIZ GarayoA, Jesús, "La creación de señoríos en la Navarra del siglo XV y su repercusión durante la Edad Moderna y el proceso de abolición", El mundo rural en la Edad Moderna, VII Reunión de la Fundación Española de Historia Moderna, ed. Universidad de Castilla la Mancha, Ciudad Real, 2004, pp. 1.203-1.229.

Vaquero Díaz, María Beatriz, Colección diplomática do mosteiro de San Salvador de Celanova (ss. XII-XV), ed. Tórculo, Santiago de Compostela, 2004, vol. I.

VÁzquez Bertomeu, Mercedes, Notarios, notarías y documentos en Santiago y su tierra en el siglo $X V$, ed. Do Castro Sada, 2001. 